\author{
И 3 Т О К Ь Т - ДА Л ЕЧ ЕН И БЛИЗ Б К \\ THE E A S T - S O FA R, S O CLOSE
}

\title{
BETWEEN NATIONALISM AND EUROPEANISM: REPRESENTATIONS OF CHINA'S BELT AND ROAD INITIATIVE IN BULGARIAN MEDIA, 2013-2018
}

\author{
Yuxiang LIN \\ UCL - University College London \\ Email: yuxiang.lin.18@ucl.ac.uk
}

\begin{abstract}
In 2013 China put forward the BRI - Belt and Road Initiative, part of its focus was to intensify investment in the countries along the Belt and Road including Bulgaria. Meanwhile Bulgaria was seeking for new foreign investment. The China's initiative did not receive any reflection in Bulgarian media during the first four years. In 2017, the first Belt and Road forum was held in Beijing. Then during the period 2017-2018, reports on the BRI started to emerge in Bulgarian media and its coverage was polarised. The papers used techniques from framing theories to present how the initiative was presented differently in selected media reports from the online newspapers Trud, Ataka, Capital and Club 'Z'. Furthermore, the research explored the reasons behind the difference from the perspectives of nationalism and Europeanism. The paper argues that the pro-European media tend to see China's initiative as a risk, while the nationalist media tend to see the BRI as an opportunity. The opportunity lies in the economic benefit from the short-term effect, while the risk is inferred from the political influence from the long-term run. From the viewpoint of political psychology, there was lack of familiarity and intensive engagement with China, which made the BRI perceived as a risk. Overall, the paper analyses bias in the Bulgarian media through the example of China's BRI.
\end{abstract}

KEYWORDS: media, BRI, framing theory, agenda-setting theory, nationalism, Europeanism, political psychology.

\section{Introduction: Research Background and Purpose}

After Bulgaria's entry into the EU (European Union) in 2007 (BBC, 2007), its economic growth was affected by the Global Financial Crisis (Terazi, Senel, 2013) and the European Debt Crisis (Christova-Balkanska, 2015). Meanwhile, China increased its economic involvement in the country. In January - October 2018, China has become one of Bulgaria's three largest trading partners (imports: 0.64 billion USD; exports: 0.55 billion USD) among all non-EU countries (Bulgarian National Statistical Institute, 2018). While the negative influence of the EU on the Bulgarian economy has been more obvious, China is strengthening its position of a key trading partner of Bulgaria among non-EU states. China's strengthening position of a trading partner is one of the five priorities that the BRI (Belt and Road Initiative) aims to pursue. China's president Xi Jinping proposed initiatives of building a Silk Road Economic Belt and the 21st Century Maritime Silk Road during his visit to Kazakhstan in September and to Indonesia in October, respectively (Yue, Cao, 2018). According to official interpretations of the Chinese government, the cooperation contents of BRI are namely policy coordination, infrastructure connectivity, unimpeded trade, financial integration and connecting people (Belt and Road Portal, 2018). These concepts existed long before the launch of BRI. Thus, BRI is not a brand-new initiative, but it is a part of new discourse in international politics. In spite of this, the new expression of old ideas has received a controversial reaction in Bulgaria. With a focus on infrastructure, finance, trade (European Bank for Reconstruction and Development), the Eurasian initiative aims to connect with both Western and Eastern Europe (Huston, 2017). However, Western Europe is already trading massively with China; for example, China's trade with Germany (87.93 billion USD) is 67 times more than that of Bulgaria (1.28 billion USD) for January-June 2018. China has a significantly larger amount of goods for import and export with Western Europe than with Eastern Europe (Ministry of Commerce of China, 2018). The chances of trade with Bulgaria to rise to a significant amount in the near future are relatively small. Despite this, Western Europe, which has a dominant voice in the European Union, is worried about China trading with Eastern Europe and sees BRI mainly as a threat to divide Europe (Jakimow, 2017). This scepticism and pressure from Brussels can turn into a barrier 
for Bulgaria to participate in China's BRI, considering Bulgaria is on the loose periphery of the EU and lacks the resources and political clout to advance its interests in Brussels (Bechev, 2018). Factors such as Bulgarian national interests and the state's conformity to the EU make China's Belt and Road Initiative a controversial and problematic issue in Bulgaria.

In this economic and political context, this coursework addresses the research question: How and why is China's BRI reported differently in Bulgarian Online Media during 2013 - 2018? I argue that media reports are polarised along nationalist and pro-European lines of division. On the one hand, nationalist newspapers see BRI as a stimulator for developing bilateral relationships that are beneficial to Bulgarian national interests; on the other hand, pro-European media outlets tend to report against the initiative and emphasize its potential risks of increasing China's political influence and undermining EU's influence on Bulgaria.

\section{Methodology and Theoretical Framework}

In this part, I will explain why I have involved Bulgarian media in the research question. Media analysis is a key part of the two mass communication, namely agenda-setting theory and framing theory; they set the theoretical framework to explain the research question. Agenda-setting theory argues that the media sets the public agenda, namely telling the audience what to think about (McCombs, Shaw, 1972); while Framing theory suggests that the way something is presented to the audience influences the choices people make about how to process that information (Chong, Druckman, 2007). Firstly, whether the media report a certain issue and the amount and type of the information used to report the issue make readers learn whether the issue is important and how much importance it carries. Secondly, the frame that is placed on the information by the media, influences the perception of the news by the audience. This offers the theoretical foundation to explain the paradox of why a certain issue does not immediately appear on the media after it comes into being, and the one and same issue delivers polarised value judgements to the audience since it is first reported. Theoretically, the media can select one of various frames to place on a certain issue to shape opinions of the audience, which will affect the audience in their political decisions such as voting. Hence, it is significantly valuable to research the problematic nature of the BRI in Bulgarian media. However, it is beyond the scope of the coursework to evaluate the effect of setting and framing on the audience's decision-taking process in political life. Instead, I will analyse the process of setting and framing of the BRI from influential Bulgarian newspapers and explore the reasons behind that.

Bulgaria's transition to democracy led to the freedom of speech in the media (Raycheva, 2016). It is politically permissible for Bulgarian media to report on a wide range of social and political topics with various value judgements. In the research of the BRI, I used the keyword poyas i put (belt and road in Bulgarian) to identify and rank the most read media reports on the BRI in Bulgarian online media. Then I used the following selection criteria: a) Content is Bulgaria-related, neither about general analysis of the BRI, nor about its non-European or purely Chinese viewpoints; $b$ ) The media outlets publishing this content are relatively popular in Bulgaria. Four articles stood out as they were more widely read by a large margin and substantially longer. Then I used the framing techniques (Fairhurst, Sarr, 1996) to compare various framing processes demonstrated in the four articles. The four articles and their press profile are as follows:

- $\quad$ 'Edin poyas, edin put, mnogo problemi' (One belt, One road, Many problems), 1896 words, published on May 2017, from Capital, pro-western media (Antonov).

- $\quad$ 'EC: S Putya na koprinata Kitai razdelya Evropa' (EU: With Its Silk Road China Separates Europe), 510 words, published on April 2018, from Club 'Z", a newly founded in 2014 news site.

- $\quad$ 'Noviyat Put na koprinata shte zaobikoli li Bulgariya' (Will The New Silk Road Bypass Bulgaria ), 1052 words, published on June 2017, from Ataka, the official newspaper of the nationalist political party 'Ataka'.

'Redaktorut $\mathrm{v}$ Kitaiskoto radio za chujbina Todor Radev pred Trud: Kitaiskite investitsii shte sa poveche, ako Bulgariya raboti za privlichaneto' (The Editor in China International Radio Todor Radev Tells Trud: There Will be More Chinese Investment, if Bulgaria Works More to Attract It), published on July 2017, from Trud, newspaper of social democracy. 


\section{Findings: Typology and Characteristics of Polarised Framings}

Firstly, I divided the time range into two periods, 2013 - 2016, and 2017 - 2018. During the first period, there were no reports towards the BRI on Bulgarian media outlets. Possible reasons are that there were no practical projects being realized under the BRI in Bulgaria and Bulgaria did not have a clear national strategy towards the BRI. The Bulgarian media did not have BRI as its reporting agenda. Bulgarian media did not realize any significance of the BRI until the Belt and Road Forum for International Cooperation was held in 2017. Thus, it was not surprising Bulgaria did not send any representatives to the forum which is regarded as the highest standard international event under the BRI framework (Ministry of Foreign Affairs of China). During the second period 2017 - 2018, some Bulgarian media started to include BRI on its agenda but shaped polarized framings of the initiative.

Capital and Club 'Z' present a negative coverage of BRI: Capital uses the European perspective to justify the non-participation of Bulgaria in the forum and $C l u b$ ' $Z$ ' criticizes the BRI using information from the German newspaper Handelsblatt. On the contrary, Ataka criticizes the nonreaction of Bulgaria towards the BRI and Trud advises how Bulgaria should benefit more from the BRI. The four articles use different framing techniques suggested by Fairhurst and Starr (1996). Originally, there are seven techniques but only three of them are observed here, namely metaphor, slogan, and spin.

a) Metaphor

A metaphor means framing a conceptual idea through comparison one thing to another thing. Bulgarian media use the concept to frame the initiative and certain action. For example, the concept of Chinese investment under the BRI is compared to 'dujdut na pari' (rain of money) (Ataka); the action of non-participation of Bulgarian government in the BRI described as 'propusna vlaka' (missed the train) (Ataka). The comparison of a sophisticated international initiative to the everyday social and natural phenomenon is understandable to even the low-educated people; it tries to convey the economic benefits of the BRI.

On the flipside, the BRI is also compared to the Marshall Plan after the Second World War (Club ' $Z$ '). The metaphor exaggerates similarities between the BRI and the Marshall Plan in terms of boosting exports, broadening financial influences. However, such metaphor ignores world context of these two ideas; one in complete chaos in 1948 while the other is relatively more organized in 2013; China in 2013 is also not as strong as the US in 1948 (Shen, Chan, 2018). The comparison of China's current initiative to an even more sophisticated historical US's plan serves mainly to frame opinions of elite groups; it conveys political implications of the BRI.

b) Slogan, jargon, catchphrase

Using a slogan means to frame an object with a catchy phrase to make it more memorable and relatable. Phrases such as 'razdelya Evropa' (break Europe) and 'zadushi svobodna turgoviya' (it stifled free trade) ( $C l u b$ ' $Z$ ') tend to attract the attention of readers immediately. These critical and sharp phrases lead to framing of EU-related negative perceptions of BRI in the mind of the audience.

From another perspective, Trud suggested 'promenyat radikalno ikonomicheskata situatsiya' (change the economic situation radically). Such an attractive and strong phrase emphasizes the economic profits of China's involvement in Bulgaria and thus guides the audience to think in a positive way of the BRI.

c) Spin

The idea of spin is to present a concept in such a way as to convey a value judgement that might not be immediately apparent. As described in media Club ' $Z$ ', '...ako Kitai ne bude nakaran da se pridurja kum evropeiskite printsipi za prozrachnost.'(if China is not made to adhere to the European principles of transparency). This sentence starts by setting us a pre-condition that China is not likely to comply with European principles, which inserts negative opinions into the frame of China's BRI.

In another group of newspapers, Trud suggested 'natsionalna garantsiya' (national guarantee) to be given by the Bulgarian government to Chinese investors. This eye-catching phrase shifts the focus from the initiative itself to the governance capacity of Bulgaria with the pre-set condition that BRI is beneficial and profitable.

Based on a), b) and c), one can see both groups of newspapers use framing techniques to convey information about the BRI. The ways in which the Bulgarian media report the BRI are related to the ways they use framing techniques to give information about the BRI. Firstly, Capital and Club 'Z' tend 
to compare the BRI to the historically sophisticated strategy with a focus of political implications; while Ataka and Trud tend to compare the BRI to the everyday phenomenon with a focus on the economic benefits. Secondly, the first uses catchy phrases to convey negative connotations on the long-term global level; while the latter uses slogans to express extremely positive immediate expectations from Bulgaria itself. Thirdly, the negative framing of the BRI is based on a hidden pre-set condition of China's rulebreaking behaviour, but the positive framing of the BRI is based on inserting a positive judgement in advance and then criticizes the Bulgarian government. In short, the BRI is reported in two ways in the Bulgarian media, namely in a negative way which considers the BRI as a risk; in a positive way that frames the initiative as an opportunity.

\section{Discussions: Explanations for Different Narratives}

a) Pro-EU vs. Nationalism Discourse

A poll from 2016 shows that Bulgaria is among the most pro-European countries in the EU (BNR). As an EU member, Bulgaria's foreign policy is influenced by EU. It can be explained both in the short term and the long term. In the short term, the EU is worried about rule-obeying, transparency and corruption issues of Chinese investment in Bulgaria. For example, China tried to manufacture cars under the brand Great Wall near the Bulgarian city Lovech with the aim to enter the European market. However, it was suspended in 2017 as their cars do not comply with EU energy efficiency requirements (Granitska, Nikolov, 2017). The Chinese foreign outbound investment faces problems of not giving enough attention to local laws (Liao, 2017). In the long term, however, the European Union has expressed concerns that China will have more political influence in CEE and will erode Europe's unity through the $16+1$ platform under BRI. Hence, the pro-EU newspapers as Capital and Club ' $Z$ ' in Bulgaria tend to perceive BRI more as a risk than an opportunity.

On the other hand, the official newspaper of the nationalist party Ataka has a different viewpoint. From a nationalist point of view, the Chinese investment in Bulgaria will bring real economic changes in society. The sinologist Radev sees parallels between joining BRI and entry into the EU. Both secure the entry of new capital into the country (Trud). The nationalist viewpoint denies EU political influence on the state's own relationships to China but insists that every member state of EU can decide themselves the relationships with China and how to approach to China.

Reactions from other CEE countries towards BRI have incited a nationalist perspective towards the initiative. The fact that Beograd-Budapest railway line bypasses Bulgaria is seen as a result of the passive reaction of Bulgaria to BRI. Even though according to official statistics of China's FDI (Foreign Direct Investment) stock in 2017, Bulgaria has received 0.25 billion USD, which is more than 0.17 billion USD compared to Serbia. This demonstrates that even though the total FDI amount from China in Bulgaria is bigger than its neighbour Serbia, there are no significant infrastructure projects built by China in Bulgaria. This causes dissatisfaction among nationalists.

b) Short-term effect vs. long-term analysis

Time ranges are also a reason for different reports of the BRI in the Bulgarian media. When it is analysed from the short-term perspective, the perspective of economic profit is more obvious and thus it is positive. BRI by its essence is about the economic cooperation between China and other countries, including Chinese investment overseas. The foreign direct investment is very important for the modernisation of the Bulgarian economy (Vesti, 2014). In 2017, the percentage of FDI (Foreign Direct Investment) of GDP (Gross Domestic Production) is 1.9\%. According to experts, a good and easily digestible level of foreign investment is about $10 \%$ of GDP. This shows that Bulgaria is in need of more foreign investments for its economic development. So the Chinese investment in the country will be beneficial from an economic perspective. The Chinese investment could potentially improve Bulgaria's economy in the short run.

However, from a long-term point of view, BRI is likely to have political implications for Bulgaria. China is believed to employ soft-power oriented economic diplomacy for BRI (Yagci, 2018). During 2013 - 2016, there is no coverage of China's BRI on the Bulgarian media; however, during $2017-2018$ there was already a focus on China's BRI. This change demonstrates that China has already increased the attention Bulgaria pays to it. Hence, the long-term effect, namely China increasing its soft power and political influence, is the main source of negative opinions.

c) Political Psychology in International Policies 
Political psychologists argue that risk is used to foster impression in international affairs (Kertzer, Tingley, 2018). The extent of involving risk in the analysis of the BRI determines the extent to which media coverage will be negative. I argue that negative opinions are not based on current real situations, but on fear for potential risks in the future. Both Capital and Club ' $Z$ ' are offering their predictions of negative influences of BRI in the future when they say that, for example, it will be very harmful if China does not adhere to European principles of transparency in their investment.

I also argue that the main reason for risk-driven opinion is a lack of first-hand experiences with China. For example, in the interview conducted by the newspaper Trud, Todor Radev, the Bulgarian news editor working in China expressed a positive attitude towards potential risks and gave constructive opinions about BRI. He has been well-informed of China and the BRI by his experience of living and working in China. Hence, from a psychological perspective, Bulgaria's lack of familiarity or engagement with China is a primary reason for concerns over BRI's risks.

V.

\section{Conclusion}

China's controversial BRI is reported in Bulgarian online newspapers from the perspectives of Bulgaria and the EU. The explanation behind that is mainly because of different political orientations of newspapers. Pro-EU newspapers like Capital and Club ' $Z$ ' are more likely to see BRI as a risk especially in its long-term political influence, while nationalist newspapers like Ataka and Trud consider the BRI as an opportunity in its short-term economic benefits. A psychological perspective also explains the lack of abundant first-hand information as the formation of negative reports.

This study applied framing theory and agenda-setting theory to explain polarisation in reports. It is beneficial for scholars in the field of China's BRI studies and investment in Eastern Europe, as well as of geopolitical relations between the EU and China. Further studies could explore the question further by evaluating the effects of BRI framing in Bulgaria.

\section{BIBLIOGRAPHY:}

Antonov, S. (2018)

BBC (2007)

BBC (2015)

Bechev, D. (2018)

Belt and Road Portal (2018)

Bulgarian National Institute (2018)

Bulgarian National Radio (2016)

Capital (2018)

Chong, D., J.

Druckman, (2017)
Digital News Report - Bulgaria. [Online Edition]. Retrieved from: $<$ http://www.digitalnewsreport.org/survey/2018/bulgaria-2018/> [Accessed on 30 Dec 2018].

Romania and Bulgaria Join the EU. [Online Edition]. Published 1 Jan 2007. Retrieved from: <http://news.bbc.co.uk/1/hi/world/europe/6220591.stm> [Accessed on 28 Dec 2018].

Bulgaria Profile - Media.' [Online Edition]. Published 13 July 2015. Retrieved from: $<$ https://www.bbc.co.uk/news/world-europe-17205118> [Accessed on $28 \mathrm{Dec}$ 2018].

Bulgaria and the European Union. [Online Edition]. Published May 2018, Retrieved from:

$<$ http://oxfordre.com/politics/view/10.1093/acrefore/9780190228637.001.0001/acr efore-9780190228637-e-508> [Accessed on 28 Dec 2018].

Shenmeshi yidaiyilu. [Online Edition]. Retrieved from: https://www.yidaiyilu.gov.cn/info/iList.jsp?tm id=540 [Accessed on 31 Dec 2018].

Exports and Imports-Preliminary Data. [Online Edition]. Published 11 Dec 2018. Retrieved from: <http://www.nsi.bg/en/content/7984/main-trade-partners $>$ [Accessed on 29 Dec 2018].

Poll Shows Bulgaria is among Most Pro-European Countries in EU. [Online Edition]. Published 1 July 2016. Retrieved from: $<$ http://bnr.bg/en/post/100645023/poll-shows-bulgaria-is-among-most-proeuropean-countries-in-eu $>$ [Accessed on 30 Dec 2018].

Chujdite investicii $\mathrm{v}$ Bulgariya namalyavat 10 puti prez poslednoto desetiletie. Published 28 Aug 2018. Retrieved from:

$<$ https://www.capital.bg/politika_i_ikonomika/bulgaria/2018/08/28/3302635_chuj

dite investicii_v bulgariia namaliavat 10 puti/> [Accessed on 30 Dec 2018].

Framing Theory. //Annual Review of Political Science 10, pp. 103 - 126. 
Christova-Balkanska, I. (2015)

Cooper, A., Heine, J., R. Thakur (2013)

European Bank for Reconstruction and Development (2018) Fairhurst, G., R. Sarr, (1996)

Goffman, E. (1974)

Granitska, L., K. Nikolov (2017)

Hutson, N. (2017)

Jakimow, M. (2017)

Kertzer, J., D. Tingley (2018)

Liao, Z. (2007)

McCombs, M., D.

Shaw (1972)

Ministry of Commerce of China (2017)

\section{Ministry of Commerce of China (2018)}

Raycheva, L. (2016)

Shen, S., W. Chan, (2018)

Terazi, E., S. Şenel (2013)

Vesti (2014)

Yagci, M. (2018)

Yue, H. \& Cao, K. (2018)
The European Debt Crisis and The Challenges To The Banking Sector In Bulgaria. // Journal of Financial and Monetary Economics, Centre of Financial and Monetary Research 2, pp. $15-22$.

Economic Diplomacy. [Online Edition]. Published Aug 2013. Retrieved from $<$ http://www.oxfordhandbooks.com/view/10.1093/oxfordhb/9780199588862.001.0 001/oxfordhb-9780199588862-e-22> [Accessed on 30 Dec 2018].

Belt and Road Initiative. [Online Edition]. Retrieved from: https://www.ebrd.com/what-we-do/belt-and-road/overview.html [Accessed on 28 Dec 2018].

The Art of Framing. San Francisco: Jossey-Bass.

Frame Analysis: An Essay on the Organization of Experience. New York, NY et al. Harper \& Row.

The Third Attempt of a Car Factory in Bulgaria Finished.' [Online Edition]. Published 28 March 2017. Retrieved from: $<$ https://www.mediapool.bg/priklyuchitretiyat-opit-za-zavod-za-koli-v-bulgaria-news261957.html $>$ [Accessed on $30 \mathrm{Dec}$ 2018].

The Belt and Road through Eurasia: Who Wins and How? [Online Edition]. Published 18 Dec 2017. Retrieved from: <https://eurasianet.org/the-belt-and-roadthrough-eurasia-who-wins-and-how $>$ [Accessed on 29 Dec 2018].

Is China's Belt and Road Initiative dividing Europe? [Online Edition]. Published 11 July 2017. Retrieved from: < $\underline{\text { http://speri.dept.shef.ac.uk/2017/07/11/is-chinas-belt- }}$ and-road-initiative-dividing-europe/ $>$ [Accessed on 28 Dec 2018].

Political Psychology in International Relations: Beyond the Paradigms. //Annual Review of Political Science. 21, pp. 1 - 23.

'qiye zouchuqu kunjing yu celue. // quanguo shangqing (jingji lilun yanjiu).

The Agenda-setting Function of the Mass Media.' [Online Edition]. // Public Opinion Quarterly 36, pp. 176 - 187.

niandu zhonggguo duiwaizhijietouzi tongjigongbao.' [Online Edition]. Published 28 Sept 2018. Retrieved from:

$<$ http://hzs.mofcom.gov.cn/article/date/201809/20180902791492.shtml $>$

[Accessed on 30 Dec 2018].

'2018nian 1-6 yue zhongguo yu ouzhouguojia maoyitongjibiao' Published 01 Oct 2018. Retrieved from:

$<$ http://ozs.mofcom.gov.cn/article/zojmgx/date/201811/20181102802046.shtml > [Accessed on 28 Dec 2018].

Transformations in the Bulgarian Media System: Tendencies and Challenges. [Online Edition]. Retrieved from

$<$ http://worldofmedia.ru/TRANSFORMATIONS\%20IN\%20THE\%20BULGARI

AN\%20MEDIA\%20SYSTEM.pdf > [Accessed on 29 Dec 2018].

A Comparative Study of the Belt and Road Initiative and the Marshall plan. // Palgrave Communications 4(32). Retrieved from: $<$ https://www.nature.com/articles/s41599-018-0077-9>[Accessed on 30 Dec 2018].

The Effects of the Global Financial Crisis on the Central and Eastern European Union Countries. // International Journal of Business and Social Science. 2. No. 17, pp. $189-192$.

Rolyata na chujdite investicii za bulgarskata ikonomika se promeni. [Online Edition]. Published 23 Sept 2014. Retrieved from: $<$ https://www.vesti.bg/analizi-ikomentari/analiz/roliata-na-investiciite-v-ikonomikata-se-promenia-6023049>

[Accessed on 30 Dec 2018].

Rethinking Soft Power in Light of China's Belt and Road Initiative. // International Relations. 15 , pp. $67-78$.

Wuzhounian! 'yidaiyilu zaichufa, xijinping de zhexietifa yiweishenyuan. [Online Edition]. Published 7 Sept 2018 // Retrieved from: $<$ http://politics.people.com.cn/n1/2018/0907/c1001-30279642.html $>$ [Accessed on 30 Dec 2018]. 